\title{
RELATIONSHIP BETWEEN PARENTING STYLES AND ACADEMIC PERFORMANCE OF JUNIOR SECONDARY SCHOOL STUDENTS IN NIGER STATE, NIGERIA
}

\author{
IBRAHIM MOHAMMED BAJI (PhD) AND AISHA I. MOHAMMED (PhD)
}

\begin{abstract}
This study investigated the influence of parenting styles on academic performance of secondary school students in Niger state, Nigeria. The study employed a correlational design to measure the relationship between parenting styles and academic performance. A sample of 380 junior secondary school students during 2013/2014 academic session was selected from public schools through simple random sampling technique. The research instrument used was Parenting Styles Questionnaire (PSQ) which measured parenting styles across authoritative parenting, authoritarian parenting, and permissive parenting styles. The PSQ was validated through content validity and had a reliability coefficients alpha of .800. The second instrument was academic achievement tests in English language and Mathematics which were developed by subject teachers teaching at the SSS level and their content and construct validity were determined by the inspectors in charge of these specialty areas at the Inspectorate Division, Ministry of Education, Minna. The statistical tools used for analysis of the data include mean, standard deviation, and Pearson Product Moment Correlations. The findings revealed that there were positive correlations between parenting styles and academic performance of JSS students with correlation values expressed as: Authoritative parenting style $(r=.154, p<0.05)$, authoritarian parenting style $(r=.102, p<0.05)$, and permissive parenting style $(r=.066, p>0.05)$. Based on the findings of this study, it is recommended that parents should encourage, support and monitor academic activities of children to improve their performance.
\end{abstract}

\section{Introduction}

Evidence from literature has identified family background and parental behaviours, students' personal characteristics, such as prior ability, self-concept, motivation, anxiety, study skills, learned helplessness, age, gender and many others as influential to academic achievement (Aboma, 2009; Adem, 2005; Tesfaye, 2007; Wudu \& Getahum, 2009). Other potential factors that exert influence on academic achievement include admission requirements, social adjustment and adoption, lack of proper counselling services, teachers' teaching and evaluation methods, school curriculum, school location and problem of measurement errors by teachers (Yalew, 2005). Hence, development of school children and their academic achievement in this sense is a product of a complex set of interacting factors; including family, school and community.

According to Bronfenbrenner (1990), children's development occur within an interactive system of nested interest which influences academic performance of school children. Developmentally, the junior secondary school (JSS) level falls within the early stage of adolescent development which is marked by dramatic cognitive changes and the development of the self as an autonomous, efficacious individual. The JSS students have at this stage increased abilities to consider multiple dimensions of academic problems when making academic decisions and anticipate the results and consequences of their success and failure. These changes and challenges influence their sense of academic achievement, and ability to make competent decisions about school matters. 
Although the role of all parents is to influence, teach, and control their children, parents may differ in the socialization process of their children. Thus, qualities of parenting styles such as spending time with children, modeling appropriate behaviours, helping children to acquire skills to develop healthy peer relationships, stating rules clearly, setting limits, being consistent in correcting inappropriate behaviours and praising good ones as well as providing a warm, secure environment have relationship with students' academic performance. Parenting style in this study, therefore, involves a combination of commitment and participation in activities on the part of parents to their children's education. It encompasses the commitment of parents in school activities of their children, time devoted in helping them in their homework and the encouragement given to them. Against this background, there are two key elements that work together to make up parenting styles which have influence on academic achievement (Vandergrift \& Greene cited in Bhatti \& Qazi, 2011). One of the elements is the level of commitment which includes: encouraging the students, being sympathetic to them, reassuring, and understanding with them. The second element is the level of parental activity and participation that involves things which are observable such as reading with students, attending school functions, and volunteering in terms of contribution to the development of school infrastructures (e.g., donations and self-help projects). Understanding how parenting styles are related to JSS3 academic goals, success and failure in this sense, needs to be examined.

\section{Statement of the Problem}

Many social contexts such as family and parenting behaviours pervade students' activities in schools which influence their academic performance. Findings of previous studies have ascertained that students achieve a greater academic performance when their parents are highly involved in their education. Similar results of some other research attribute blame parents for being negligent to students' needs which eventually lead to their academic failure. Parenting styles in this perspective, therefore, is seen as a factor that exerts influence on students' academic performance but its effect could be either in positive or negative direction. In view of this, available literatures in Niger State have shown a record of falling standard of education manifested in poor academic performance of the students of which the attribution factor is multi-dimensional (Niger State Ministry of Education, 2013). Consequent upon this, this study is necessitated to investigate whether or not parenting styles influence academic performance among JSS students in Niger state.

\section{Research Questions}

The following research questions were used to guide the conduct of this study:

i. Is there any relationship between authoritative parenting style and academic performance of junior secondary school students?

ii. Is there any relationship between authoritarian parenting style and academic performance of junior secondary school students?

iii. Is there any relationship between permissive parenting style and academic performance of junior secondary school students? 


\section{Research Hypotheses}

This research tested the following null hypotheses:

$\mathrm{H}_{01}$ : There is no significant relationship between authoritative parenting style and academic performance of junior secondary school students.

$\mathrm{H}_{02}$ : There is no significant relationship between authoritarian parenting style and academic performance of junior secondary school students.

$\mathrm{H}_{03}$ : There is no significant relationship between permissive parenting style and academic performance of junior secondary school students.

\section{Literature Review}

Parenting style is defined by Santrock (2007), as a psychological term that centers on the behaviour and attitude of parents, representing standard strategies that they use in their child rearing process. Parenting style is the process of promoting and supporting the physical disambiguation needed for emotional, social and intellectual development of a child from infancy to adulthood. In other words, parenting style is the emotional climate in which parenting practices take place (e.g., tone of voice, burst of anger, display of empathy, etc.). These behaviours, according to Darling and Steinberg (1993), comprised parenting practices as well as other aspects of child-interactions that communicate emotional attitude but are not goal directed (e.g., tone of voice, body language, inattention, burst of temper and so on). The concept of academic achievement, on the other hand, is viewed as doing or achieving at school: in a class, in a laboratory, in a library or in a fieldwork (Fuligni, 1997 \& Watabe, 2011). Academic achievement refers to students' examination grades at the end of a particular academic semester or educational programme. Egbule, (2004) defined academic performance as the level of performance in a particular field of study, which higher scores indicate better achievement and lower scores reveals poor achievement.

There are three classification of parenting styles: authoritative (warm and firm), authoritarian (firm but not warm) and permissive (warm but not firm); and all the styles have been linked to children's developmental outcomes including academic achievement (Rita, 2008 \& Baumrind, 1973). This classification focused on four important aspects of family functioning, namely: nurturance or warmth, firmness and clarity of control, level of maturity demands, and degree of communication between parents and children (Baumrind, 1973, 1991). Maccoby and Martin (1983) extended the work of Baumrind by incorporating the notion of parental reinforcement (Rita, 2008). This involves the degree of demand and control as well as the degree of acceptance and rejection. According to Maccoby and Martin (1983), these two dimensions jointly create four types of parenting styles. These are: Authoritative (high demandingness and high responsiveness), authoritarian (high demandingness and low responsiveness), indulgent (low demandingness and high responsiveness) and rejecting (low demandingness and low responsiveness). Darling and Steinberg (1993) maintained that to understand the processes through which parenting style influences children's development, three different aspects of parenting must be disentangled: the goals toward which socialization is directed; the parenting practices used by parents to help children reach those goals; and the parenting styles or emotional climate, within which socialization occurs. 
In attempt to relate parenting styles to child's social behaviour and academic performance therefore, an examination of parents' attitudes, age, gender and temperament are needed (Alsheikh, Parameswaran, \& Elhoweris, 2010; Haris, 2002). Comrade and Ho, (2001) found that mothers' parenting style had a bigger impact on children's performance in school while Bronte-Tinkew, Moore and Carrano, (2006) found that father's emotional responsiveness was more highly related to children's academic performance. Thus, the foundation for parenting styles and academic performance is formed by the belief systems and attitudes of the parents. Pastorelli, Coprara, Barbaranelli, Rola, Rozsa, and Bandura, (2001) found that children with authoritarian training perceive themselves as less efficacious for self-directed learning, and those enhanced by authoritative parents show higher academic competence, social development, self-perception and mental health (Lamborn, Mounts, Steinberg, \& Dornbusch, 1991, Maccoby \& Martin, 1983). In this context, parenting factors such as involvement in school and parent-child interactions (warmth and affection) are significantly related to children's academic performance (Brown \& Lyenger, 2008; Watabe, 2011).

\section{Methodology}

This study adopted a correlational research design. A correlational design was considered useful and appropriate because the study measured the relationship between parenting styles and academic performance of JSS 3 students.

\section{Sample}

The target population of this study was all 105,034 JSS 3 students 2013/2014 academic session from 206 public junior secondary schools that were independent from senior schools in Niger State (Niger State Ministry of Education, 2013). The sample size was 380 students, drawn from 20 junior secondary schools that were selected randomly. This size was determined using Krejcie and Morgan (1970) table for determining sample size from a given population. The multistage and proportionate random sampling procedures were employed. A multistage sampling was used to divide the State into three senatorial zones (i.e., Niger North, Niger East and Niger South) and then into Local Government Areas. Three schools were selected randomly from 6 local government areas; out of which a sample of the respondents for the study was obtained. A simple random sampling was used to select the respondents from each school through hat and draw method.

\section{Instrumentation}

The questionnaire instrument and scores of JSS 3 students 2013/2014 session in English Language and Mathematics Achievement Tests were used to collect data in this study. Parenting Style Questionnaire (PSQ) was employed as the instrument to measure students' reports about parenting styles used on them by their parents. This was modified and developed by the researcher after studying Parental Authority Questionnaire (PAQ) by Buri, (1991) and Questionnaire on Parenting Styles by Chandler, (2006). The PSQ contains 38 items covering authoritative parenting style, authoritarian parenting style, and permissive parenting style. The response format used for the PSQ instrument was 5-point Likert's scale with options ranging from Strongly Agree (SA), Agree (A), Not Decided (ND), Disagree 
(DA) and Strongly Disagree (SDA), which were scored 5, 4, 3, 2, and 1 respectively. The English Language Achievement Test (ELAT) and Mathematics Achievement Test (MAT) on the other hand, were developed by the subject teachers of English and Mathematics teaching at the JSS level in order to measure students' academic performances in the areas. Each of the two instruments has 20 multiple-choice items and scored five (5) marks out of onehundred marks. Thus, a respondent could score a maximum of 200 marks ( 5 x 40) for the two tests as well as a minimum of zero mark $(0 \mathrm{x} 40)$.

\section{Validity and Reliability of the Instruments}

The instruments in this study were validated through content validity. Experts in Educational Psychology, Measurement and Evaluation and Guidance and Counselling from the Ahmadu Bello University, Zaria evaluated the contents of the PSQ items and made necessary corrections and modifications to ascertain their appropriateness and content coverage with reference to the research objectives. A pilot testing of the PSQ instrument was conducted on 30 students of a separate portion of the population in May, 2013. The reliability was determined using Cronbach Alpha in Statistical Package for Social Science (SPSS) 21.0 version and it had alpha value of .800 .

\section{Procedure for Data Collection}

The collection of data in this study was done by the researcher with the aid of four research assistants. Permission to undertake the research was sought and approved by the State Ministry of Education. The principals of the selected schools were informed about the purpose of the study and the researcher was therefore granted access to the JSS 3 classes. Prior to the proper administration of the instruments, the students were briefed about the nature and objectives of the study and also assured of keeping secret of all the information they had provided. The instrument was administered to students by group method during normal class time but in a room specifically set aside for the purpose of the research. Participants completed the questionnaire in approximately 30 minutes duration in the presence of a research assistant. Where there was a problem of literacy and difficulty by some students, the researcher read the items aloud and verbatim. The students were thanked for participating in the study.

\section{Procedure for Data Analysis}

The statistical analysis was performed in the study using SPSS 21.0 version. Mean, standard deviation and Pearson Product Moment Correlations (PPMC) were employed to test the null hypotheses.

\section{Hypotheses Testing}

\section{Hypothesis 1}

$\mathrm{H}_{01}$ : There is no significant relationship between authoritative parenting style and academic performance of junior secondary school students. 
Table 1: $\quad$ Pearson Product Moment Correlation Analysis between Authoritative Parenting Style and Academic Performance of JSS Students

\begin{tabular}{llllll}
\hline Variables & Mean & SD & r & df & p-value \\
\hline Authoritative Parenting & 82.2000 & 12.22104 & $.154^{* *}$ & 378 & .001 \\
Academic Performance & 103.8529 & 23.57558 & & & \\
\hline
\end{tabular}

** Correlation is significant at 0.01 levels (2-tailed).

Table 1 showed that there was a statistically significant positive relationship between authoritative parenting style and academic performance of JSS students in Niger state $(\mathrm{r}=$ $.154, \mathrm{df}=378, \mathrm{p}<0.01$ ). On the basis of this result, since the $\mathrm{p}$-value is less than 0.01 , the null hypothesis which stated that there was no significant relationship between authoritative parenting style and academic performance of JSS students in Niger state was rejected. This result signified that as authoritative parenting style increased, academic performance of the JSS students also increased.

\section{Hypothesis 2}

$\mathrm{H}_{02}$ : There is no significant relationship between authoritarian parenting style and academic performance of junior secondary school students.

Table 2: $\quad$ Pearson Product Moment Correlation Analysis between Parenting Style Academic Performance of JSS Students

\begin{tabular}{llllll}
\hline Variables & Mean & SD & r & df & p-value \\
\hline Authoritarian Parenting & 35.7747 & 6.34890 & $.102^{*}$ & 378 & .033 \\
Academic Performance & 103.8529 & 23.57558 & & & \\
\hline
\end{tabular}

* Correlation is significant at 0.05 levels (2-tailed).

The output on Table 2 revealed that there was a statistically significant positive relationship between authoritarian parenting and academic performance of JSS students in Niger state ( $\mathrm{r}=$ $.102, \mathrm{df}=378, \mathrm{p}<0.05)$ ). Thus, since the $\mathrm{p}$-value was less than 0.05 , the null hypothesis which stated that there was no significant relationship between authoritarian parenting style and academic performance was rejected. This meant that the higher the authoritarian parenting style the more it influenced academic performance of the JSS students.

\section{Hypothesis 3}

$\mathrm{H}_{03}$ : There is no significant relationship between permissive parenting style and academic performance of junior secondary school students.

Table 3: Pearson Product Moment Correlation Analysis between Permissive Parenting Style and Academic Performance of JSS Students

\begin{tabular}{llllll}
\hline Variables & Mean & SD & r & df & p-value \\
\hline Permissive Parenting & 23.1310 & 7.38530 & .066 & 378 & .168 \\
Academic Performance & 103.8529 & 23.57558 & & & \\
\hline
\end{tabular}


The findings on Table 3 showed that there was positive relationship between permissive parenting style and academic performance of JSS students in Niger state. However, the relationship was not statistically significant $(\mathrm{r}=.066, \mathrm{df}=378, \mathrm{p}>0.05)$. Therefore, since the p-value was greater than 0.05 , the null hypothesis which stated that there was no significant relationship between permissive parenting style and academic performance of JSS students was accepted. This implied that permissive parenting style did not increase academic performance of JSS students in Niger State.

\section{Discussions}

The study findings revealed positive correlations between parenting styles and academic achievements among JSS 3 students in Niger State. Previous research had yielded consistent evidence with the findings of this study. For example, the study of Kordi and Barharudin, (2010) revealed that authoritative parenting was associated with higher levels of children's school achievements in the United States, while authoritarian parenting was higher in relation with academic achievements among Chinese and Asian children. The reason behind these differences as Garcia and Martinez (2007) asserted, was that American parents promoted authoritativeness, while Asian parents reinforced the value of 'Filial piety'; commonly known as unquestioning obedience to parents, and Chinese parents were described as controlling or authoritarians. Previous empirical research conducted in colleges and universities among different ethnic groups in United States of America, Japan, China, Ethiopia and Nigeria had demonstrated that authoritative parenting style had a significant positive effects and relationships on academic performance among students than other styles (Abesha, 2012; Chad, Herb, \& Jamie, 2006; Chao, 2001; Chandler, 2006, \& Yusuf, Agbonna, \& Yusuf, 2009). The analysis of Yusuf, Agbonna, Yusuf (2009) on influence of parenting styles among JSS students in social studies performance in Ilorin Emirates also reported that authoritative parenting style had influence on students' performance than other types with chi-square ratio 308, 713a, df 12, and $\mathrm{P}<0.05$. Cramer (2002), in his study of influence of parenting styles on children's classroom motivation among third grade students in a Mid-sized Southern city, reported, in agreement with this study, that mothers' authoritative parenting was positively related to first graders' mastery motivation; fathers' authoritarian parenting was negatively related to first graders' mastery motivation; mothers' permissive parenting was negatively related to teachers' perception of children's classroom motivation, and fathers' authoritarian parenting was positively related to third graders' mastery motivation.

The findings of Watabe, (2011) were also in support of the results of this study. Watabe, (2011) examined the influence of parenting on children's academic achievements between the United States and Japan and found that American children acquired the benefits of academic achievements with authoritarian parenting today and no support was recorded about the contemporary Japanese children in terms of higher academic achievement in respect of authoritative parenting style. Similarly, the study of Alsheikh, Parameswaran, \& Elhoweris, (2010) on impact of parenting and self-esteem on academic performance in the United Arab Emirates found that demandingness was significantly related to academic performance ( $\mathrm{r}=.29)$. As Alsheikh et al., (2010) and Juan and Larry, (2004) further posited, it was found that in China, authoritarian parenting was positively related to children's 
performance in school while there was no similar positive impact for authoritative parenting and permissive parenting styles. On this basis, Chao, (2001:1112) analyzed that Chinese parenting involved being very strict but maintaining a high level of control, which made children to be disciplined and obedient to social order.

\section{Conclusions and Recommendations}

In line with the findings of this study, it could reasonably be inferred that parenting styles consistently have a crucial role on academic achievement of students through provision of a robust parenting style functioning that influence the general well-being of children across a wide spectrum within diverse communities. The outcomes of this study revealed that authoritative and authoritarian parenting styles had positive relationship with students' academic performance. In a nutshell, it was obviously noted from the results of this study that various factors were responsible for the development and progress of students' academic performance, out of which was parenting styles. In view of the foregoing, the following recommendations were made:

i. Authoritative parenting style should be encouraged to provide the home environment with instructional materials and to provide room for assisting students in terms of homework for good learning opportunities for school children among students.

ii. Schools should organize seminars and workshops for parents on importance of authoritative parenting and academic support through Parents' Teachers' Association and School-Based Management Committee (SBMC) to enhance students' academic performance. Workshops and courses have the advantage to teach parents ways to improve the quality of verbal interactions that can produce immediate, positive effects on children's intellectual development and academic growth.

iii. Since academic performance is a learned behaviour, it is important for parents to recognize that serious efforts are needed to provide solid background for early children's educational experiences through authoritarian parenting style.

iv. Parents' resource centers should be opened in individual schools with accessible local public library and information technology communication to boost school-parents' communication for good permissive parenting.

v. Parents' education programmes should be introduced in schools to provide a unique strategy and framework for preventive approach on students' academic failure as a remedy for laxity which characterized permissive parenting style.

\section{References}

Abesha, A. G. (2012). Effects of parenting styles, academic self-efficacy and achievement motivation on academic achievement of university students in Ethiopia. PhD Dissertation, Edith Cowan University, Addis Ababa.

Aboma, O. (2009). Predicting first year university student's academic success. Electronic Journal of Research in Educational Psychology, 7 (3), 1053- 1072. 
Adem, K. (2005). Factors affecting students' performance in higher institutions: The case of Alemaya University. Journal of the Ethiopia Statistical Associations, 14: 73- 82.

Alsheikh, N.; Parameswaran, G., \& Elhoweris, H. (2010). Parenting style, self-esteem and student performance in the United Arab emirates. Current Issues in Education, 13 (1): 124.

Baumrind, D. (1973). The development of instrumental competence through socialization. In A. Pick (Eds.), Minnesota symposium on Child psychology (pp. 3-46). Minneapolis, MN: University of Minnesota Press.

Baumrind, D. (1991). The influence of parenting style on adolescent competence and substance use. Journal of Early Adolescence, 11 (1): 56-95.

Bhatti, M. T., \& Qazi, W. (2011). Parental support, self-concept, motivational orientations, teacher-student relationship, and academic competence: An exploratory analysis. Cypriot Journal of Educational Sciences, 4 (2): 203- 214.

Bronfenbrenner, U. (1990). Discovering what families do. In rebuilding the nest: A new commitment to the American family. family service, America. Retrieved on 31/12/2014. From http://www.montanaedu/www4h/process.html

Bronte-Tinkew, J., Moore, K. A., \& Carrano, J. (2006). The father-child relationship: Parenting styles and adolescent risk behaviours in intact families. Journal of Family Issues, 27 (6): 850-881.

Brown, L., \& Iyengar, S. (2008). Parenting Styles: The impact on student achievement. Marriage \& Family Review, 43 (12): 14- 38.

Buri, J. R. (1991). Parental authority questionnaire. Journal of Personality Assessment, 57(1): 110- 119.

Chandler, M. (2006). The influence of parenting style and ethnicity on academic self-efficacy and academic performance. Texas A \& M University.

Chao, R. K. (2001). Extending research on the consequences of parenting style for Chinese Americans and European Americans. Child Development, 72 (5):1832-1843.

Comrade, G., \& Ho, R. (2001). Differential parenting styles for fathers and mothers: Differential treatment for sons and daughters. Australian Journal of Psychology, 53 (1): 29-35.

Darling, N. \& Steinberg, L. (1993). Parenting styles as context: An integrated model. Psychological Bulletin, 113 (3): 487- 496. 
Egbule, J. F. (2004). Practical guide to a successful project or thesis in writing and defense. Owerri: Whyte and Whyte Publishers.

Fuligni, A. J. (1997). The academic achievement of adolescents from immigrant families: The roles of family background, attitudes and behaviour. Child Development, 68 (2): 351363.

Garcia, J. F., \& Martinez, I. (2007). Parenting styles and adolescents' self-esteem in Brazil. Psychological Reports, 100 (6): 731- 745.

Harris, J. R. (2002). Monographs in parenting. In J. G. Borkowski \& S. L. Ramey, (Ed.); Parenting and the child's world: Influences on academic, intellectual and social emotional development. Mahwah: Lawrence ErIbaum Associates Publishers.

Juan, H. \& Larry, P. (2004). Chinese parenting styles and children's self-regulated learning. Journal of Research in Childhood Education, 2 (4): 55-64.

Krejcie, R., \& Morgan, D. W. (1970).Determining sample size for research activities. Retrieved on 25 September, 2014 from www.https//opa.uprrp.edu/.../Krejc...

Lamborn, S., Mounts, N., Steinberg, L., \& Dornbusch, S. (1991). Patterns of competence and adjustment among adolescents from authoritative, authoritarian, indulgent, and neglectful homes. Child Development, 62 (10): 49-65.

Niger State Ministry of Education, Minna (2013). Department of Research, Planning and Statistics. Minna: MOE.

Maccoby, E. E., \& Martin, J. A. (1983). Socialization in the context of the family: Parentchild interaction. In E. M. Hetherington (Ed.), Socialization, Personality, And Social Development: Vol. 4. Handbook of Child Psychology. New York: Wiley.

Pastorelli, C., Caprara, G. V., Barbaranelli, C. Rola, J., Rozsa, S., \& Bandura, A. (2001). The structure of children's perceived self-efficacy: A cross- national study. European Journal of Psychological Assessment, 17 (2): 87- 97.

Rita, F. D. (2008). The impact of early childhood poverty on academic achievement and influence of supporting parenting. Unpublished $\mathrm{PhD}$ dissertation, University of Rochester, Rochester, New York.

Santrock, J. W. (2007). A topical approach to life-span development ( $3^{\text {rd }}$ ed). New York NY: McGraw-Hill.

Tesfaye, S. (2007). Identification of factors contributing to gender disparity in an Ethiopia University. Eastern Africa Social Science Research Review, 23 (2): 71-93. 
Watabe, A. (2011). The Influence of Parenting on Children's Academic Achievement: Comparison between the United States and Japan. A Master of Arts Thesis, California State University, Chio.

William, H. J. (2005). Parental involvement and student achievement: A meta-analysis. Family involvement research digest. Harvard: USA.

Wudu, M., \& Getahun, F. (2009). Trend and causes of female students' dropout from teacher education institutions of Ethiopia: The case of Jimma University. Ethiopia Journal of Education Science, 5 (1): 1-19.

Yalew, E. (2005). The effects of grade, self-efficacy, learned-helplessness and cognitive engagement on liking mathematics among primary school students. Ethiopian Journal of Development Research, 27 (2): 81-107.

Yusuf, A., Agbonna, S.A., \& Yusuf, H.T. (2009). Influence of parenting styles on junior secondary school students' performance in social studies in Ilorin emirate. Nigerian Journal of Social Studies, 12 (2): 35-49. 